\title{
Molecular Detection and Differentiation of Erwinia pyrifoliae and Host Range Analysis of the Asian Pear Pathogen
}

Won Sik Kim and Susanne Jock, Max-Planck-Institut für Zellbiologie, Rosenhof, D-68526 Ladenburg, Germany; Jean-Pierre Paulin, UMR Pathologie Végétale INRA, INH, Université d'Angers, 42, rue Georges Morel, B.P. 57, 49071 Beaucouze, France; Seong-Lyul Rhim, Department of Genetical Engineering, College of Natural Science, Hallym University, 1 Okcheon-Dong, Chuncheon-Si, Kangwon-Do, 200-702, South Korea; and Klaus Geider, Max-Planck-Institut für Zellbiologie, Rosenhof, D-68526 Ladenburg, Germany

\begin{abstract}
Kim, W.-S., Jock, S., Paulin, J.-P., Rhim, S.-L., and Geider, K. 2001. Molecular detection and differentiation of Erwinia pyrifoliae and host range analysis of the Asian pear pathogen. Plant Dis. 85:1183-1188.

The recently described pathogen Erwinia pyrifoliae, isolated from Nashi pear fruit trees in Korea, resembles the fire blight pathogen Erwinia amylovora in some of its properties. The two pathogens were classified into different species by DNA hybridization kinetics and microbiological criteria. From the nucleotide sequences of the 16S rRNA and the internal transcribed spacer (ITS) region as well as extracellular polysaccharide (EPS)-encoding genes, polymerase chain reaction (PCR) primers were designed that specifically detect $E$. pyrifoliae but not the fire blight pathogen Erwinia amylovora, and these primers were also applied to identify E. pyrifoliae in necrotic plant material. The genomes of several strains were digested with the restriction enzyme SpeI, and the DNA fragments were analyzed by pulsed-field gel electrophoresis (PFGE). Three groups of patterns could be distinguished for the isolated E. pyrifoliae strains, all different from various E. amylovora strains, which produce a relatively homogeneous PFGE pattern after SpeI digests. Typical fire blight host plants were assayed in a growth chamber or an experimental field for their susceptibility to E. pyrifoliae. A strong preference was found for pear varieties, whereas apple, cotoneaster, hawthorn, or raspberry rarely produced necrotic symptoms. E. pyrifoliae was readily detected in samples from pear orchards in South Korea during 1995 to 1998; however, the Asian pear pathogen was not recovered in necrotic plant tissue from 1999 and 2000.
\end{abstract}

Additional keywords: Asian pear blight, disease rating

Erwinia pyrifoliae is a pathogen isolated from necrotic Asian pear fruit trees (Pyrus pyrifolia Nakai) in Korea (13). Symptom formation on immature pears and its colony morphology on MM2Cu agar are similar to those of Erwinia amylovora, the causative agent of fire blight. However, microbiological assays, negative polymerase chain reaction (PCR) using primers specific for $E$. amylovora (13), and BIOLOG/biotype 100 analysis and DNA-DNA hybridization kinetics distinguished $E$. pyrifoliae from the fire blight pathogen E. amylovora and from Enterobacter pyrinus $(5,11)$. E. pyrifoliae was isolated in four consecutive years (1995 to 1998) from Korean orchards in the Chuncheon region exclusively from a diseased Nashi pear tree.

Many assays have been previously described for detection and identification of E. amylovora (10). The addition of $2 \mathrm{mM}$

Corresponding author: K. Geider
E-mail: kgeider@zellbio.mpg.de

Accepted for publication 19 July 2001.

Publication no. D-2001-0910-01R

(C) 2001 The American Phytopathological Society
(EPS) synthesis and to the yellow color formation of the colonies $(2,17)$, an effect also seen with E. pyrifoliae (13). In contrast to other methods such as description of the colony morphology, serological assays, fatty acid profiles, and phage typing, PCR assays were more specific and sensitive $(1,3)$. Detection of E. amylovora by PCR was conducted with two primer pairs derived from plasmid pEA29 (3) and the ams genes (encoding amylovoran synthesis) (4). Ribosomal RNA (rRNA) genes are widely used for taxonomy to classify bacteria at the levels of species, orders, or even kingdoms (14). At the species level, the rRNA operon, including a noncoding internal transcribed spacer region (ITS), has been successfully used to differentiate E. pyrifoliae from E. amylovora (11). Pulsed field gel electrophoresis (PFGE) is another powerful tool to differentiate $E$. amylovora strains (16,18; S. Jock, W.-S. Kim, V. Donat, M. M. Lopez, C. Bazzi, and K. Geider, unpublished). Although the PFGE patterns of E. amylovora isolates from Europe and the Mediterranean region are closely related, a single band can be used for distinction of strains from large regions. proved detection of E. amylovora due to an increase of extracellular polysaccharide
A.

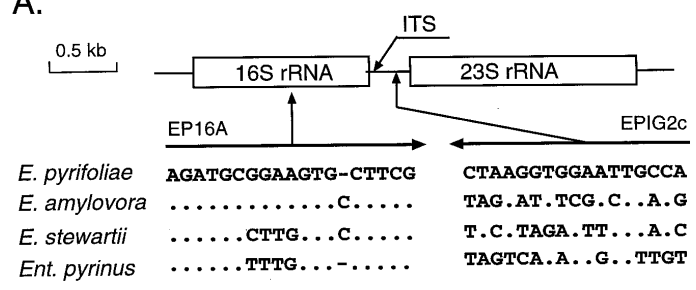

B.

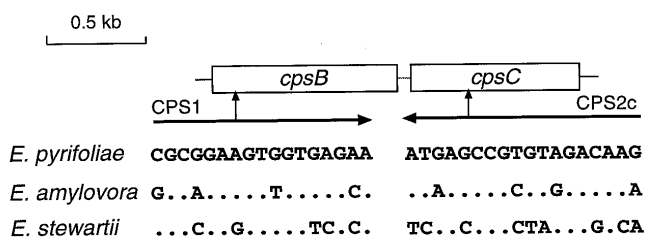

Fig. 1. A scheme for the design of primers for specific detection of Erwinia pyrifolia via rRNA (A) and cps (B) genes. Nucleotide sequences of DNA fragments covering the primer regions were aligned with a minimal allowance of gaps in the corresponding regions of other pathogens. Base pairs matching with the E. pyrifoliae nucleotide sequence (first line) are indicated by dots. The nucleotide sequences with accession numbers listed in Material and Methods were derived from E. pyrifoliae Ep1/96, Erwinia amylovora Ea1/79, Erwinia stewartii DC283, and Enterobacter pyrinus 90.2, respectively. 
In this study, we created two specific PCR primer pairs for specific detection of E. pyrifoliae and PFGE analysis to differentiate E. pyrifoliae strains, and we also assayed the host range of the pathogen by challenging common fire blight host plants.

\section{MATERIALS AND METHODS}

Design of primers for detection of $\mathrm{Er}$ winia pyrifoliae. The nucleotide sequences of the 16S rRNA and the ITS RNA regions of various Erwinia strains were previously determined (11) and deposited in the EMBL Nucleotide Sequence Database with the accession numbers AJ009930 for E. pyrifoliae strain Ep1/96, AJ132969 for E. pyrifoliae strain Ep16/96 (ITS only), AJ010485 for E. amylovora strain Ea1/79, and AJ010486 for Enterobacter pyrinus strain 90.2. For EPS-encoding regions, the nucleotide sequence entries are AJ300463 for cps genes of E. pyrifoliae and X77921 for the ams region of E. amylovora.

The nucleotide sequences from the rRNA regions of E. pyrifoliae, E. amylovora, Erwinia stewartii, and Enterobacter pyrinus were aligned to design PCR primers specific for $E$. pyrifoliae. At position 1004 in the 16S rRNA of E. pyrifoliae and 1738 in the ITS of E. pyrifoliae, appropriate sequences were found, and primers EP16A (5'-AGATGCGGAAGTGCTTCG) and EPIG2c (5'-ACCGTTAAGGTG GAATC) were created (Fig. 1A). For the $16 \mathrm{~S}$ rRNA, an insertion of one nucleotide after position 13 of the primer differed for E. pyrifoliae and E. amylovora, whereas primer sequences from the ITS region were largely divergent from E. amylovora and even more from E. stewartii and Enterobacter pyrinus.

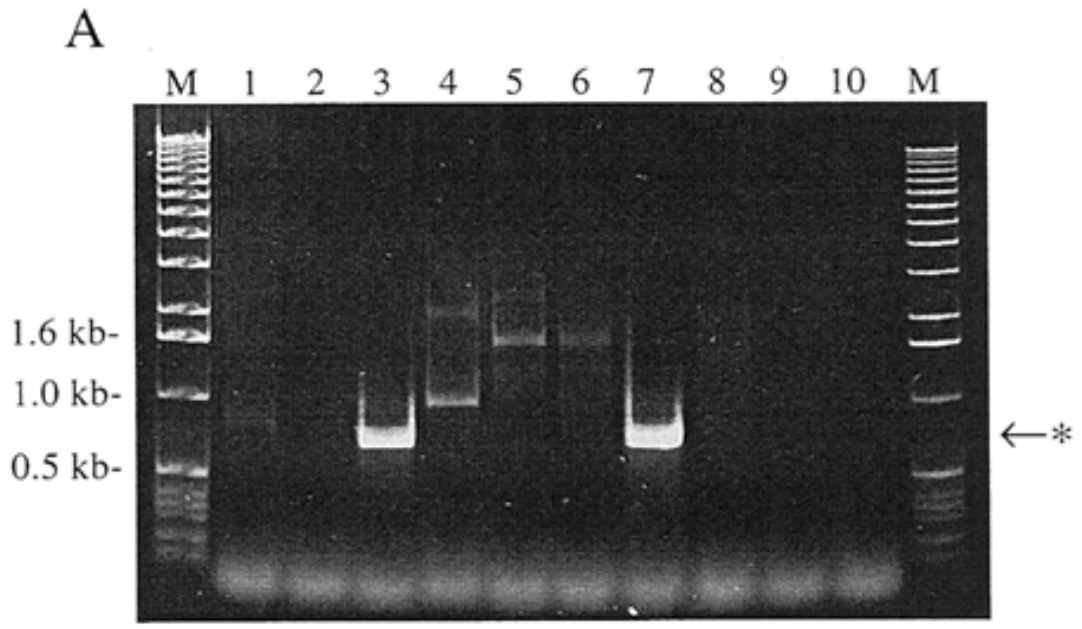

$\mathrm{B}$

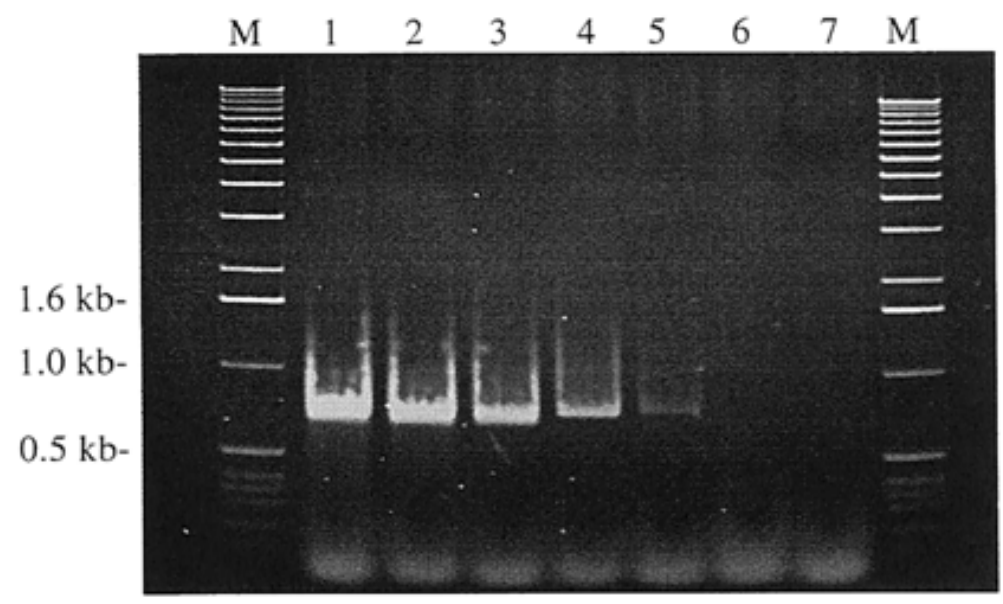

Fig. 2. A, Detection of Erwinia pyrifoliae with the primer pair EP16A/EPIG2c. Lane 1, Erwinia herbicola; 2, Escherichia coli; 3, E. pyrifoliae Ep1/96; 4, Enterobacter pyrinus; 5, Erwinia stewartii; 6, Pseudomonas syringae; 7, extract from a necrotic pear seedling inoculated with $E$. pyrifoliae Ep1/96; 8, Xanthomonas campestris; 9, Erwinia amylovora Ea1/79; 10, water control; $\leftarrow *$ indicates the position of $0.73 \mathrm{~kb}$, expected for E. pyrifoliae. B, Sensitivity in polymerase chain reaction (PCR) detection of $E$. pyrifoliae with rRNA primers. Cells from an overnight culture of $E$. pyrifoliae strain Ep1/96 $\left(2 \times 10^{9}\right.$ bacteria per $\left.\mathrm{ml}\right)$ were stepwise diluted for the PCR assays. In lanes 1 to 6 , aliquots with $2 \times 10^{5}, 10^{4}, 10^{3}, 10^{2}, 10^{1}$, and $10^{0} \mathrm{CFU}$ were assayed. Lane 7 , water control; M, marker of 1$\mathrm{kb}$ ladder DNA (sizes of bands at the left border).

To design a PCR primer pair corresponding to primers of the ams region of $E$. amylovora (4), DNA fragments with parts of $c p s B$ and cpsC from the EPS encoding region of $E$. pyrifoliae were cloned and sequenced. The selected E. pyrifoliae primers CPS1 (5'-CGCGGAAGTGGT GAGAA) and CPS2c (5'-GAACAGATG TGCCGAGTA) differed from E. amylovora by four nucleotides and were even more divergent to the corresponding cpsE/F genes of E. stewartii (6) (Fig. 1B). Primer CPS1 is located at position 5714 and CPS2c at position 6935 of the E. pyrifoliae cps region.

PCR analysis. The PCR was done in 50 $\mu \mathrm{l}$ with $10 \mathrm{ng}$ of template DNA or $1 \mu \mathrm{l}$ of a $10^{-4}$ dilution of overnight grown bacterial cultures under conditions described previously $(3,11)$ with $0.5 \mathrm{U}$ of $T$ th DNA polymerase or $2 \mathrm{U}$ of Taq DNA polymerase and 25 pmol of primers. PCR assays were carried out in an Eppendorf mastercycler 5330. The DNA was denatured for $1 \mathrm{~min}$ at $95^{\circ} \mathrm{C}$, and amplification was done in 30 cycles applying $95^{\circ} \mathrm{C}$ for $15 \mathrm{~s}, 52$ or $57^{\circ} \mathrm{C}$ for $15 \mathrm{~s}$, and $72^{\circ} \mathrm{C}$ for $30 \mathrm{~s}$. Following electrophoresis in a $0.8 \%$ agarose gel and staining with ethidium bromide, the PCR products were visualized under UV light.

Plant material was extracted by placing about $100 \mathrm{mg}$ of tissue in an Eppendorf tube with $1 \mathrm{ml}$ of sterile water for $30 \mathrm{~min}$. Liquid was removed and up to $10 \mu \mathrm{l}$ applied to the PCR assay or aliquots plated first on LB agar with cycloheximide (50 $\mu \mathrm{g} / \mathrm{ml}$, to avoid fungal growth).

PFGE analysis. PFGE analysis was done as described for E. amylovora (16).

Host range assays. E. pyrifoliae strains were inoculated in an experimental field on adult trees of a range of Rosaceous plants, among them genotypes of hawthorn (Crataegus sp.), apple (Malus sp.), and pear (Pyrus sp.), as well as plum (Prunus salicina) and raspberry (Rubus idaeus). Actively growing shoots were inoculated just below the apex with a syringe, infiltrating up to $0.05 \mathrm{ml}$ of a $10^{8} \mathrm{CFU} / \mathrm{ml}$ suspension of 24-h-old culture. Three shoots of each of three trees per genotype were inoculated. Four weeks after inoculation, the length of necrotic lesions on shoots was assessed. Response was considered positive when at least one-third of the inoculated shoots showed a necrosis of more than $2 \mathrm{~cm}$ in length. E. amylovora strains CFBP3049, a highly virulent isolate from apple (Canada), Ea1/79 from Cotoneaster sp. (Germany), and CFBP2151 or IL6 from Rubus idaeus (United States) were used in the study. Four E. pyrifoliae strains were applied; data presented were only for the most virulent strain, Ep1/96.

When plantlets were inoculated in a growth chamber, leaf tips of young seedlings were cut with scissors and inoculated with a toothpick dipped into 
an overnight culture of an E. amylovora or E. pyrifoliae strain $\left(5 \times 10^{9} \mathrm{CFU} / \mathrm{ml}\right)$. Symptoms were monitored after 2 weeks, and obvious leaf necrosis was considered to be a positive reaction.

\section{RESULTS}

Detection of $E$. pyrifoliae by specific PCR primers. PCR amplification with primers EP16A and EPIG2c gave a band at $0.7 \mathrm{~kb}$ with $E$. pyrifoliae but not with $E r$ winia herbicola, Escherichia coli, Enterobacter pyrinus, E. stewartii, Pseudomonas syringae, Xanthomonas campestris, or E. amylovora (Fig. 2A), nor with other bacteria of the former species of Erwinia and other plant-associated bacteria listed in Tables 1 and 2 (data not shown). When large amounts of cells $\left(>10^{6} \mathrm{CFU}\right)$ were applied, shadow bands above $0.7 \mathrm{~kb}$ were visible with Enterobacter pyrinus and $E$. stewartii. The sensitivity of the primers was assayed with a series of dilutions. The minimal concentration of bacterial cells to obtain a signal was approximately $20 \mathrm{CFU}$ per assay (Fig. 2B). Direct detection of $E$. pyrifoliae from necrotic pear leaves gave a positive signal without any shadow bands. Healthy pear leaves were a negative control.

Primers CPS1 and CPS2c were also assayed with several bacterial species (Fig. 3A), including selected erwinias (Table 1) and other plant-associated erwinias (Table 2 ). The $1.2-\mathrm{kb}$ PCR product was only detected with E. pyrifoliae. Extracts from necrotic pear leaves inoculated with $E$. pyrifoliae also gave a positive signal. Occasionally, nonspecific weak bands of different sizes were obtained with $E$. herbicola, E. coli, and P. syringae, especially at an annealing temperature of $52^{\circ} \mathrm{C}$. An annealing temperature of $57^{\circ} \mathrm{C}$ reduced shadow bands, but also sensitivity. PCR detection of $E$. pyrifoliae was done in the range from $2 \times 10^{5}$ to $2 \mathrm{CFU}$, and the signal was still obtained for $200 \mathrm{CFU}$ per assay using an annealing temperature of $52^{\circ} \mathrm{C}$ (Fig. 3B). The CPS primer pair is therefore slightly less sensitive for detection of E. pyrifoliae than the primers from the $16 \mathrm{~S}$ rDNA/ITS region.

PFGE analysis of various $E$. pyrifoliae strains. Several E. pyrifoliae strains in our collection were assayed by PFGE analysis after digestion with the restriction enzymes SpeI (Fig. 4) and XbaI. For XbaI, the E. pyrifoliae strains were related in their band patterns (data not shown). For SpeI digests, the 10 strains assayed were divergent in part and could be grouped into the PFGE pattern types PtA, PtB, and PtC (Table 3), which were all different from the SpeI pattern of E. amylovora strains (Fig. 4). Based on XbaI digests, E. amylovora strains can be differentiated by the resulting DNA fragments. Although the patterns diverge often only in the size of one or two DNA fragments, many strains from Europe and the Mediterranean region could grouped into the pattern types Pt1 to Pt6 with a rare occurrence of unusual types (16,18; S. Jock, W.-S. Kim, V. Donat, M. M. Lopez, C. Bazzi, and K. Geider, unpub-

lished). On the other hand, the patterns are quite homogeneous for the SpeI fragments of E. amylovora, even when the strains were derived from different geographical

Table 1. Strains used in this study ${ }^{\mathrm{a}}$

\begin{tabular}{|c|c|c|}
\hline $\begin{array}{r}\text { Species } \\
\text { Strain }\end{array}$ & Relevant characteristics (host, origin, year) & $\begin{array}{l}\text { Reference or } \\
\text { source }\end{array}$ \\
\hline \multicolumn{3}{|c|}{ Erwinia pyrifoliae } \\
\hline Ep1/96 & $\begin{array}{l}\text { Pyrus pyrifolia (Nashi pear), South Korea, } 1996 \\
\text { (CFBP4171, DSM12162) }\end{array}$ & 13 \\
\hline Ep4/97 & $\begin{array}{l}\text { P. pyrifolia, South Korea, } 1997 \\
\text { (DSM12394) }\end{array}$ & This work \\
\hline Ep8/95 & $\begin{array}{l}\text { P. pyrifolia, South Korea, } 1995 \\
\text { (DSM12393) }\end{array}$ & 13 \\
\hline Ep16/96 & $\begin{array}{l}\text { P. pyrifolia, South Korea, } 1996 \\
\text { (CFBP4172, DSM12163) }\end{array}$ & 13 \\
\hline Ep28/96 & $\begin{array}{l}\text { P. pyrifolia, South Korea, } 1996 \\
\text { (CFBP4173) }\end{array}$ & 13 \\
\hline Ep31/96 & $\begin{array}{l}\text { P. pyrifolia, South Korea, } 1996 \\
\text { (CFBP4174) }\end{array}$ & 13 \\
\hline Ep44/97 & P. pyrifolia, South Korea, 1997 & This work \\
\hline Ep53/97 & P. pyrifolia, South Korea, 1997 & This work \\
\hline Ep60/97 & P. pyrifolia, South Korea, 1997 & This work \\
\hline Ep102/98 & P. pyrifolia, South Korea, 1998 & 13 \\
\hline \multicolumn{3}{|c|}{ Erwinia amylovora } \\
\hline Ea1/79 & Cotoneaster sp., Northern Germany, 1979 & 8 \\
\hline CFBP3049 & Malus sp., Canada & CFBP \\
\hline CFBP1367 & Crataegus sp. (hawthorn), Lille, 1972, J.P. Paulin & 16 \\
\hline $\mathrm{S} 59 / 5$ & $\begin{array}{l}\text { type strain, } P \text {. communis, England, } \\
\text { obtained as CFBP1232 }\end{array}$ & CFBP \\
\hline $\mathrm{Ea} 4 / 82$ & P. communis cv. Le Conte, Egypt, 1982 & 18 \\
\hline Ea775 & Crataegus sp., England, 1959, NCPPB775 & 18 \\
\hline 115.22 & Cydonia oblonga (quince), Bulgaria, 1989 & 18 \\
\hline CFBP2151 & Rubus idaeus, USA & CFBP \\
\hline IL6 & R. idaeus, Illinois, USA & C. Bazzi \\
\hline \multicolumn{3}{|c|}{ Erwinia stewartii } \\
\hline DC283 & Zea mays, USA & 7 \\
\hline \multicolumn{3}{|c|}{ Erwinia herbicola } \\
\hline $48 \mathrm{~b} / 90$ & Soybean, Jena, Germany & 15 \\
\hline \multicolumn{2}{|c|}{ Erwinia chrysanthemi } & D. Coplin \\
\hline \multicolumn{3}{|c|}{ Enterobacter pyrinus } \\
\hline \multicolumn{3}{|c|}{ Xanthomonas campestris } \\
\hline XCC356 & Germany & M. Nachtigall \\
\hline \multicolumn{3}{|c|}{ Pseudomonas syringae } \\
\hline PSB17 & P. communis, Wädenswil, Switzerland, 1986 & W. Zeller \\
\hline \multicolumn{3}{|c|}{ Escherichia coli } \\
\hline C600 & K12 strain & Lab collection \\
\hline
\end{tabular}

${ }^{a}$ CFBP, Collection Française des Bactéries Phytopathogènes; DSM, Deutsche Sammlung von Mikroorganismen und Zellkulturen; KCTC, Korean Collection of Type Cultures. In recent nomenclature, Erwinia stewartii is Pantoea stewartii subsp. stewartii, and Erwinia herbicola has been named Pantoea agglomerans.

Table 2. Properties of Erwinia strains on minimal medium with copper ions and in polymerase chain

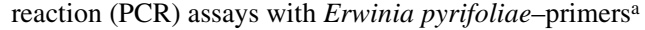

\begin{tabular}{|c|c|c|c|c|c|}
\hline Erwinia & Strain & MM2Cu & MM1Cu & ITS primers & CPS primers \\
\hline mallotivora & CFBP2503 & - & - & - & - \\
\hline quercina $^{\mathrm{B}}$ & CFBP3617 & - & - & - & - \\
\hline rubrifaciens ${ }^{\mathrm{B}}$ & CFBP3619 & - & - & - & - \\
\hline psidii & CFBP3627 & - & - & - & - \\
\hline cacticida $^{\mathrm{P}}$ & CFBP3628 & - & - & - & - \\
\hline salicis $^{\mathrm{B}}$ & CFBP802 & - & - & - & - \\
\hline tracheiphila & CFBP2355 & - & - & - & - \\
\hline cypripedii $^{\mathrm{P}}$ & CFBP3613 & $(+) / \mathrm{nm}$ & $(+) / \mathrm{nm}$ & - & - \\
\hline persicinus & CFBP3622 & $+/ \mathrm{mc}, \mathrm{yl}$ & $+/ \mathrm{mc}, \mathrm{yl}$ & - & - \\
\hline rhapontici & CFBP3618 & $+/ \mathrm{nm}$ & $+/ \mathrm{nm}$ & - & - \\
\hline nigrifluens & CFBP3616 & $(+)$ & - & - & - \\
\hline pyrifoliae & Ep1/96 & $+/ \mathrm{mc},(\mathrm{yl})$ & - & + & + \\
\hline amylovora & $\mathrm{Ea} 1 / 79$ & $+/ \mathrm{mc}, \mathrm{yl}$ & - & - & - \\
\hline
\end{tabular}

${ }^{\mathrm{a}}+$, growth or positive PCR signal; -, no growth or no PCR signal; mc, mucoid; nm, nonmucoid; yl, yellow colonies; (yl), yellowish. Some Erwinia species have been recently renamed: ${ }^{\mathrm{B}}$, Brenneria $;{ }^{\mathrm{P}}$, Pectobacterium. ITS primers $=\mathrm{EP} 16 \mathrm{~A}$, EIG2c $;$ CPS primers $=\mathrm{CPS} 1, \mathrm{CPS} 2 \mathrm{c}$. 
A

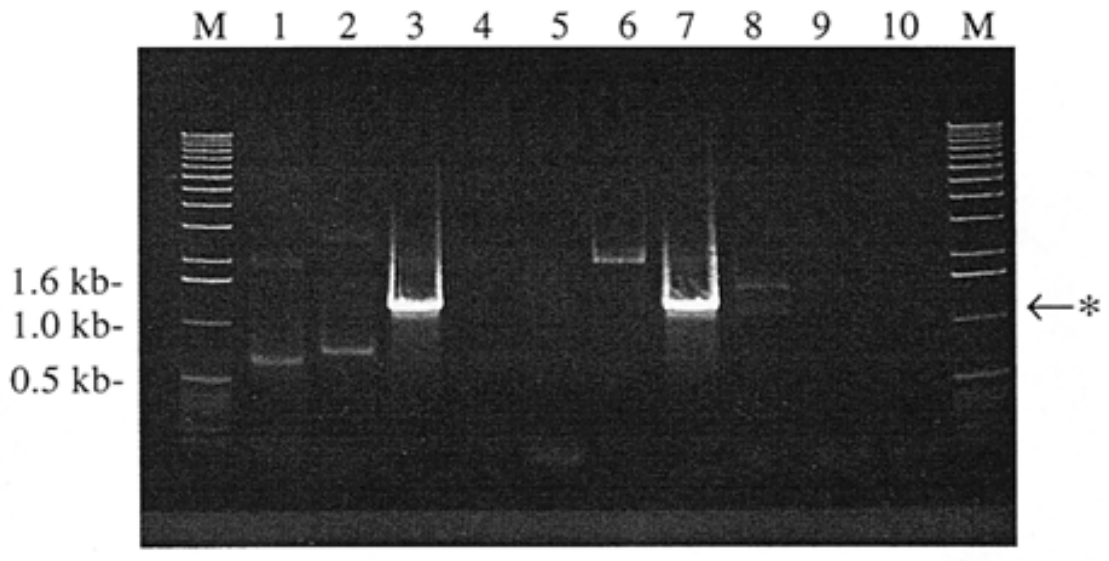

B

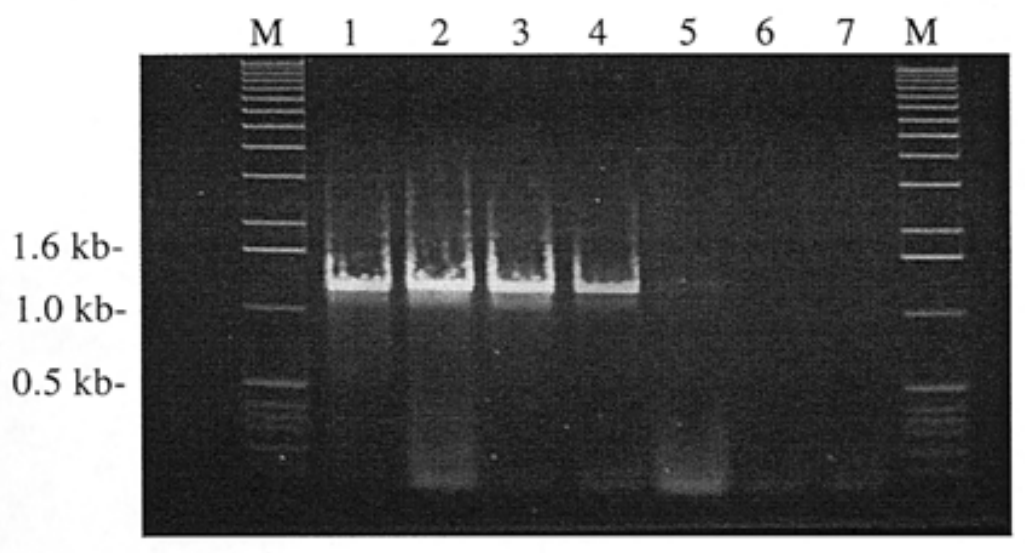

Fig. 3. A, Detection of Erwinia pyrifoliae with primers CPS1/CPS2c. Lane 1, Erwinia herbicola; 2, Escherichia coli; 3, E. pyrifoliae Ep1/96; 4, Enterobacter pyrinus; 5, Erwinia stewartii; 6, Pseudomonas syringae; 7, Extract from a necrotic pear seedling inoculated with E. pyrifoliae; 8, Xanthomonas campestris; 9 , Erwinia amylovora Ea1/79; 10, water control; $\leftarrow *$ indicates the position of $1.2 \mathrm{~kb}$, expected for E. pyrifoliae Ep1/96. B, Sensitivity of detection of E. pyrifoliae with CPS primers. Cells from an overnight culture of E. pyrifoliae Ep1/96 ( $2 \times 10^{9}$ bacteria per $\left.\mathrm{ml}\right)$ were diluted in steps of 10 . In lanes 1 to 6 , aliquots with $2 \times 10^{5}, 10^{4}, 10^{3}, 10^{2}, 10^{1}$, and $10^{0} \mathrm{CFU}$ were assayed. Lane 7 : water control; $\mathrm{M}$, marker of 1 -kb ladder DNA (sizes of bands at the left border). The annealing temperature was $52^{\circ} \mathrm{C}$.

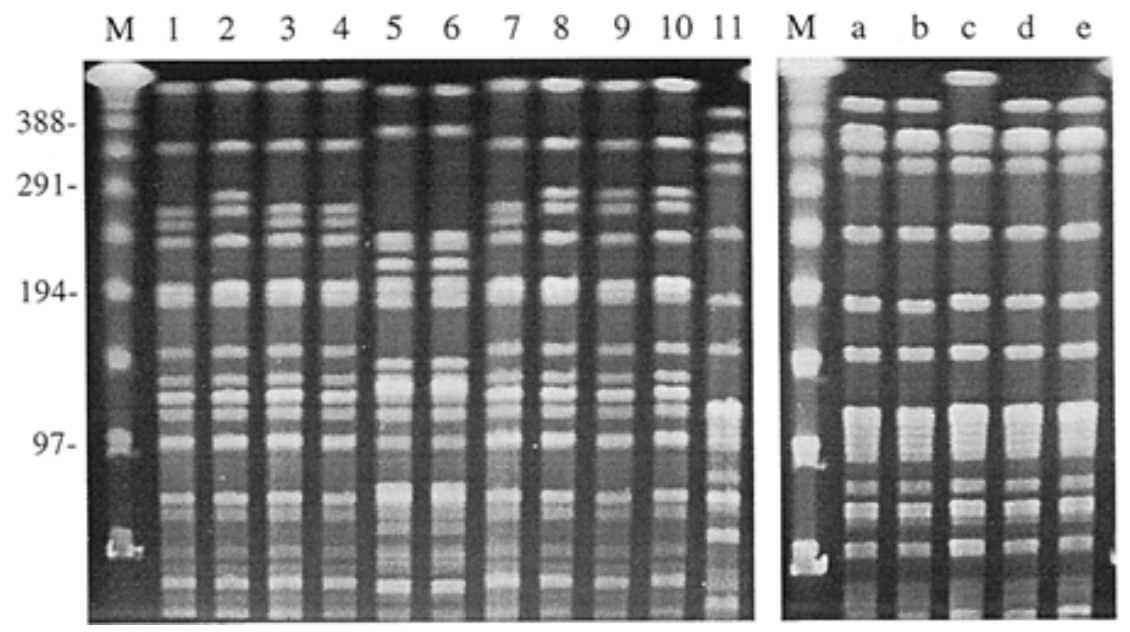

Fig. 4. Pulsed-field gel electrophoresis (PFGE) analysis of various Erwinia pyrifoliae and Erwinia amylovora strains. The genomic DNA was digested with SpeI for all lanes. (left) Lane: 1, Ep1/96; 2, Ep4/97; 3, Ep8/95; 4, Ep16/96; 5, Ep28/96; 6, Ep31/96; 7, Ep102/98; 8, Ep44/97; 9, Ep53/97; 10, Ep60/97 (all E. pyrifoliae); 11, Ea1/79 (E. amylovora). (right) Lane a, S59/5 (classified with an XbaI digest as pattern type Pt1); b, Ea4/82 (Pt2); c, CFBP1367 (Pt3); d, Ea775 (Pt4); e, 115.22 (Pt5). Conditions for PFGE were: $21 \mathrm{~h}, 5 \mathrm{~V} / \mathrm{cm} ; 129 \mathrm{~mA}$; the ramping time was $1 \mathrm{~s}$ to $25 \mathrm{~s}$. M, DNA marker of multimeric $\lambda$ genomes (sizes in $\mathrm{kb}$ at the left border). regions and various times of isolation (Fig. 4 , lane 11 and lanes a to e). Only Pt3strains show a large SpeI-fragment at 800 $\mathrm{MDa}$, a band missing from most other $E$. amylovora strains. For E. pyrifoliae, the pattern types PtA and $\mathrm{PtB}$ were closely related to each other and differed only in the position of one band. The strains grouped into PtA were isolated in 1995 , 1996, and 1998 in orchards near Chuncheon in South Korea. This indicates a conservation of the pattern during at least 3 years. Pattern type $\mathrm{PtC}$ is represented in strains from 1996 and is quite diverged from the two other pattern types. The data show a pronounced tendency of E. pyrifoliae to occur in distinguishable strains within a small area of their isolation. Explanations for the RFLPs could be a high tendency for genome changes or the occurrence of different strains independently evolved in this area.

Assays for the host range of $E$. pyrifoliae. Several fire blight host plants were challenged with pathogenic strains of $E$. pyrifoliae and E. amylovora, including rubus variants (CFBP2151 and IL6). In field assays, the $E$. amylovora fruit tree strain CFBP3049 was positive for most pear and apple cultivars, hawthorn (one exception), and cotoneaster, but only for one of the four Prunus salicina cultivars tested and negative for the raspberry cultivars (Table 4). In growth chamber experiments, seedlings from open pollinated apple (Golden Delicious), European pear (Pyrus communis cv. Bartlett), Asian pear (P. pyrifolia), and cotoneaster (Cotoneaster pannosus) were inoculated at the tips of leaves, which were cut off with scissors. The E. pyrifoliae strain Ep1/96 produced necrosis only on leaves of Asian and European pear seedlings, but not on apple seedlings (Table 4). In the experimental orchard, pathogen suspensions were injected into shoot tips. Strain Ep1/96 produced good symptoms on most pear cultivars. Strains Ep16/96, Ep28/96, and Ep31/96 were also positive, but less virulent. To a low degree, the four E. pyrifoliae strains produced weak symptoms on some apple cultivars, such as Ep1/96 on Idared, but never on hawthorn, cotoneaster, raspberry, or plum (Table 4). The host range of E. pyrifoliae is thus largely restricted to pear, with little impact on apple and none for other host plants such as hawthorn or cotoneaster. The data were confirmed by inoculation of $C$. pannosus, which is highly susceptible for fire blight. E. amylovora strain Ea1/79 readily produced necrotic symptoms in contrast to $E$. pyrifoliae strain Ep1/96 and the rubus strain IL6.

Detection of $E$. pyrifoliae by PCR assays in necrotic plant tissue including field studies. Besides leaves from inoculated Nashi pear seedlings grown in a growth chamber, necrotic tissues (branches, leaves, small pear fruits) from 
diseased Nashi pear trees of an orchard near Chuncheon (South Korea) were extracted in 1997-98, and positive signals were obtained with primer pairs EP16A/EPIG2c and CPS1/CPS2c. In addition, the pathogen was also isolated on agar plates, and E. pyrifoliae was confirmed by PCR assays. In a sample with intermediate to strong PCR signals, about $1,000 \mathrm{CFU} / \mathrm{g}$ of plant material was recovered.

Several attempts were made to isolate $E$. pyrifoliae from Korean Nashi pear orchards in 1999 and 2000. In three orchards near Chuncheon in South Korea, samples of necrotic tissue were taken from 150 Nashi pear fruit trees in the late growth season 1998. The orchards had been treated before with chemicals containing copper hydroxide and streptomycin. Dilutions of the water extracts from leaves or bark were plated on LB-agar and white colonies transferred on $\mathrm{MM} 2 \mathrm{Cu}$ agar. Cells of yellowish mucoid colonies were screened with primers CPS1 and CPS2 (from the cps region) and with EP16A and EPIG2c (from the 16S rRNA/ITS region) (Fig. 1), and no correct amplification product was obtained. With primers CPS1 and CPS2c, a false band above $1.2 \mathrm{~kb}$ was visible for some of these strains, and a HaeIII digest produced DNA fragments different from 653, 273, 210, and 86 bp expected and confirmed for the PCR product of E. pyrifoliae.

\section{DISCUSSION}

E. pyrifoliae, the causative agent of Asian pear blight, was isolated from orchards in the region of Chuncheon in South Korea (13). The occurrence of the disease in other Korean regions with growth of Nashi pears has not been reported. After sanitary measurements in presumably affected orchards, Asian pear blight has not been recently detected again, even at sites of its original isolation. To facilitate screening for $E$. pyrifoliae, two PCR primer pairs were designed, based on the $16 \mathrm{~S}$ rRNA/ITS region and the cps region corresponding to the ams region of E. amylovora (4). The primer pair from the cps genes of E. pyrifoliae can also detect Erwinia strains from Japan (12), but not $E$.

Table 3. Classification of Erwinia pyrifoliae strains according to their pulsed-field gel electrophoresis (PFGE) pattern after an SpeI digest

\begin{tabular}{ll}
\hline PFGE pattern & Strain \\
\hline PtA & Ep1/96 \\
& Ep8/95 \\
& Ep16/96 \\
& Ep102/98 \\
& Ep4/97 \\
PtB & Ep44/97 \\
& Ep53/97 \\
& Ep60/97 \\
& Ep28/96 \\
PtC & Ep31/96 \\
\hline
\end{tabular}

amylovora, the causative agent of fire blight, which has not been described to occur in Korea. The rRNA primers for detection of $E$. pyrifoliae were only positive for a part of the Japanese Erwinia strains assayed (12).

Differences in the genomes of E. pyrifoliae and E. amylovora were further confirmed by PFGE analysis. Digestion of a large number of E. amylovora strains from different regions and times of isolation indicated a high conservation of PFGE patterns (16), especially for digests with restriction enzyme SpeI (Fig. 4, right panel). Digests with $X b a I$ produced typical patterns which allowed their grouping for large regions of the Mediterranean area and of Europe (16,18; S. Jock, W.-S. Kim, V. Donat, M. M. Lopez, C. Bazzi, and K. Geider, unpublished). Spontaneous changes of PFGE patterns of E. amylovora strains apparently occur during long times of their natural propagation and distribution. $E$. amylovora strains of PFGE pattern type $\mathrm{Pt} 2$, obtained from an $\mathrm{Xba \textrm {I }}$ digest, were isolated in Egypt, where fire blight appeared first in the 1960s and then spread to Israel, Turkey, Greece, the Balkans, and to Hungary, where the disease was first detected in 1996. In contrast, E. pyrifoliae has been isolated in a narrow area within South Korea. All E. pyrifoliae strains of 1997 were isolated from a sample derived from one diseased Nashi pear tree, so a

Table 4. Disease rating of fire blight host plants after inoculation with Erwinia pyrifoliae and Erwinia amylovora strains

\begin{tabular}{|c|c|c|c|}
\hline $\begin{array}{l}\text { Plant species } \\
\text { Cultivar }\end{array}$ & E. amylovora & E. pyrifoliae & E. amylovora \\
\hline & CFBP3049 & Ep1/96\$ & CFBP2151 (Rubus) $\$$ \\
\hline $\begin{array}{l}\text { Cotoneaster sp. } \\
\text { Skogolm }\end{array}$ & $++^{\mathrm{b}}$ & - & ND \\
\hline $\begin{array}{l}\text { Crataegus } \\
\text { folia lavallei } \\
\text { grignonensis } \\
\text { oxyacantha paulii } \\
\text { oxyacantha punicea } \\
\text { seedling } 27.61 \\
\text { seedling } 28.23 \\
\text { tanacetifolia } \\
\text { turkestanica }\end{array}$ & $\begin{array}{l}+ \\
- \\
+ \\
+ \\
+ \\
+ \\
+ \\
+\end{array}$ & $\begin{array}{l}- \\
- \\
- \\
- \\
- \\
- \\
- \\
-\end{array}$ & $\begin{array}{l}\text { ND } \\
\text { ND } \\
\text { ND } \\
\text { ND } \\
\text { ND } \\
\text { ND } \\
\text { ND } \\
\text { ND }\end{array}$ \\
\hline $\begin{array}{l}\text { Malus domestica } \\
\text { Golden Delicious } \\
\text { Idared } \\
\text { Prairie fire } \\
\text { Prima } \\
\text { Repinaldo Picon } \\
\text { Xuanina } \\
\text { hupehensis }\end{array}$ & $\begin{array}{l}+ \\
+ \\
+ \\
+ \\
+ \\
+ \\
+\end{array}$ & $\begin{array}{l}- \\
+ \\
- \\
- \\
- \\
- \\
-\end{array}$ & $\begin{array}{l}\text { ND } \\
\text { ND } \\
\text { ND } \\
\text { ND } \\
\text { ND } \\
\text { ND } \\
\text { ND }\end{array}$ \\
\hline $\begin{array}{l}\text { Prunus salicina } \\
\text { Angelo } \\
\text { Fortune } \\
\text { Friard } \\
\text { hybrid (INRA) }\end{array}$ & $\begin{array}{l}- \\
+ \\
- \\
-\end{array}$ & $\begin{array}{l}- \\
- \\
- \\
-\end{array}$ & $\begin{array}{l}\text { ND } \\
\text { ND } \\
\text { ND } \\
\text { ND }\end{array}$ \\
\hline $\begin{array}{l}\text { Pyrus communis } \\
4703 / 78 \\
\text { Conférence } \\
\text { Harrow Gold } \\
\text { Harrow Sweet } \\
\text { HW614 } \\
\text { HW619 } \\
\text { hybrid (INRA) } \\
\text { Old Home } \\
\text { US 65.063.13 }\end{array}$ & $\begin{array}{l}+ \\
+ \\
+ \\
+ \\
+ \\
+ \\
+ \\
+ \\
+\end{array}$ & $\begin{array}{l}+ \\
- \\
- \\
+ \\
- \\
- \\
+ \\
+ \\
+\end{array}$ & $\begin{array}{l}\text { ND } \\
\text { ND } \\
\text { ND } \\
\text { ND } \\
\text { ND } \\
\text { ND } \\
\text { ND } \\
\text { ND } \\
\text { ND }\end{array}$ \\
\hline $\begin{array}{l}\text { Rubus idaeus } \\
\text { Heritage } \\
\text { Malling Promise } \\
\text { Wawi }\end{array}$ & $\begin{array}{c}- \\
- \\
- \\
\mathrm{Ea} 1 / 79 * \mathrm{c}\end{array}$ & $\begin{array}{c}- \\
- \\
- \\
\text { Ep1/96* }\end{array}$ & $\begin{array}{c}+ \\
+ \\
+ \\
\text { IL6 (Rubus)* }\end{array}$ \\
\hline $\begin{array}{l}\text { Cotoneaster pannosus } \\
\text { Malus domestica } \\
\text { Golden Delicious }\end{array}$ & $\begin{array}{c}\mathrm{Ea} / 1 / 19 \mathrm{e} \\
+ \\
+\end{array}$ & $\begin{array}{c}\text { Ep1/96 } \\
- \\
-\end{array}$ & $\begin{array}{c}\text { IL6 (Rubus)* } \\
- \\
-\end{array}$ \\
\hline $\begin{array}{l}\text { Pyrus communis } \\
\text { Bartlett } \\
\text { P. pyrifolia }\end{array}$ & $\begin{array}{l}+ \\
+\end{array}$ & $\begin{array}{l}+ \\
+\end{array}$ & $\begin{array}{l}\text { ND } \\
\text { ND }\end{array}$ \\
\hline
\end{tabular}


unique PFGE pattern can be expected. On the other hand, the population of E. pyrifoliae in this plant tissue was not homogeneous, because part of the isolates were HRnegative with the same PFGE-pattern as the HR-positive isolates (S. Jock, W.-S. Kim, and K. Geider, unpublished). For isolates from different samples, the PFGE pattern of an SpeI digest was quite diverse, and the isolated strains could be grouped into three pattern types. There are no data on how long Asian pear blight could have existed in Korea before its first described isolation in 1995. Divergent PFGE patterns could thus reflect slow independent evolution of strains within that area or introduction from other regions or just a higher tendency of $E$. pyrifoliae for genome changes than those observed for E. amylovora. Most recently, the pear pathogen has not been isolated in Korea. For isolation attempts during the late growth season, other bacteria could have replaced $E$. pyrifoliae in the affected plant tissue, or weak necrotic symptoms could have been caused by other microorganisms. The pathogen also could not be isolated in early growth seasons from Nashi pear fruit trees nor from necrotic tissue of apple trees (cv. Fuji). Accordingly, recent phytosanitary measurements in possible affected orchards could have reduced or even eliminated $E$. pyrifoliae in the region of Chuncheon in South Korea.

The host range of E. pyrifoliae is apparently limited to pears, especially Asian pears (Pyrus pyrifolia), but it can also infect European pears. Apple cultivars can occasionally produce slight symptoms. Clear symptoms were not observed for several fire blight host plants, although among more than 200 species (9), others might exist that are susceptible to E. pyrifoliae. For some plants such as apricots, cherry, or even strawberries, E. amylovora can be an opportunistic pathogen (16) without an ability to persist in those plants. It is possible that more plants than the described hosts can contribute to the spread of fire blight. Asian pear blight may also be able to infect more plants than Nashi pears and could also persist in plants without obvious symptom formation. Specific primers for sensitive detection of E. pyrifoliae are therefore convenient tools, not only to identify Asian pear blight on diseased Nashi pear trees, but also to trace the pathogen in asymptomatic plant tissue.

\section{LITERATURE CITED}

1. Bereswill, S., Bugert, P., Bruchmüller, I., and Geider, K. 1995. Identification of Erwinia amylovora by PCR with chromosomal DNA. Appl. Environ. Microbiol. 61:2636-2642.

2. Bereswill, S., Jock, S., Bellemann, P., and Geider, K. 1998. Identification of Erwinia amylovora by growth morphology on agar containing copper sulfate and by capsule staining with lectin. Plant Dis. 82:158-164.

3. Bereswill, S., Pahl, A., Bellemann, P., Zeller, W., and Geider, K. 1992. Sensitive and species-specific detection of Erwinia amylovora by PCR-analysis. Appl. Environ. Microbiol. 58:3522-3526.

4. Bugert, P., and Geider, K. 1995. Molecular analysis of the ams operon required for exopolysaccharide synthesis of Erwinia amylovora. Mol. Microbiol. 15:917-933.

5. Chung, Y. R., Brenner, D. J., Steigerwalt, A. G., Kim, B. S., Kim, H. T., and Cho, K. Y. 1993. Enterobacter pyrinus sp. nov. an organism associated with brown leaf disease of pear trees. Int. J. Syst. Bacteriol. 43:157-161.

6. Coplin, D. L., Majerczak, D. R., Bugert, P., and Geider, K. 1996. Nucleotide sequence analysis of the Erwinia stewartii cps gene cluster for synthesis of stewartan and comparison to the Erwinia amylovora ams cluster for synthesis of amylovoran. Acta Hortic. 411:251-257.

7. Coplin, D. L., Rowan, R. G., Chisholm, D. A., and Whitmoyer, R. E. 1981. Characterization of plasmids in Erwinia stewartii. Appl. Environ. Microbiol. 42:599-604.

8. Falkenstein, H., Bellemann, P., Walter, S., Zeller, W., and Geider, K. 1988. Identification of Erwinia amylovora, the fireblight pathogen, by colony hybridization with DNA from plasmid pEA29. Appl. Environ. Microbiol.
54:2798-2802.

9. Jock, S., Rodoni, B., Gillings, M., Kim, W.S., Copes, C., Merriman, P., and Geider, K. 2000. Screening of ornamental plants from the Botanic Gardens of Melbourne and Adelaide for the occurrence of Erwinia amylovora. Australas. Plant Pathol. 29:120-128.

10. Jones, A. L., and Geider, K. 2001. Gramnegative Bacteria, Erwinia amylovora Group. Pages 40-55 in: Laboratory Guide for Identification of Plant Pathogenic Bacteria. 3rd ed. N. W. Schaad, J. B. Jones, and W. Chun, eds. American Phytopathological Society, St. Paul, MN.

11. Kim, W.-S., Gardan, L., Rhim, S.-L., and Geider, K. 1999. Erwinia pyrifoliae sp. nov., a novel pathogen that affects Asian pear trees (Pyrus pyrifolia Nakai). Int. J. Syst. Bacteriol. 49:899-906.

12. Kim, W.-S., Hildebrand, M., Jock, S., and Geider, K. 2001. Molecular comparison of pathogenic bacteria from pear trees in Japan and the fire blight pathogen Erwinia amylovora. Microbiology/UK. In press.

13. Rhim, S.-L., Völksch, B., Gardan, L., Paulin, J. P., Langlotz, C., Kim, W.-S., and Geider, K. 1999. An Erwinia species, different from Erwinia amylovora, causes a necrotic disease of Asian pear trees. Plant Pathol. 48:514-520.

14. Villard, L., Kodjo, A., Borges, E., Maurin, F. and Richard, Y. 2000. Ribotyping and rapid identification of Staphylococcus xylosus by 16-23S spacer amplification. FEMS Microbiol. Lett. 185:83-87.

15. Völksch, B., Nüske, J., and May, R. 1996. Characterization of two epiphytic bacteria from soybean leaves with antagonistic activities against Pseudomonas syringae pv. glycinea. J. Basic Microbiol. 36:453-462.

16. Zhang, Y., and Geider, K. 1997. Differentiation of Erwinia amylovora strains by PulsedField Gel Electrophoresis. Appl. Environ. Microbiol. 63:4421-4426.

17. Zhang, Y., Jock, S., and Geider, K. 2000. Genes of Erwinia amylovora involved in yellow color formation and release of a lowmolecular-weight compound during growth in the presence of copper ions. Mol. Gen. Genet. 264:233-240.

18. Zhang, Y., Merighi, M., Bazzi, C., and Geider, K. 1998. Genomic analysis by Pulsed-Field Gel Electrophoresis of Erwinia amylovora strains from the Mediterranean region including Italy. J. Plant. Pathol. 80:225-232. 